\title{
PERBEDAAN MOTIVASI BERPRESTASI SISWA KELAS IV, V, DAN VI SEKOLAH DASAR
}

\author{
Puji Astuti \\ e-mail: astuti_fuji22@yahoo.com \\ Sekolah Tinggi Ilmu Kesehatan (STIK) Bina Husada Palembang \\ Jl. Syech Abdul Somad No. 28 Kel. 22 Ilir Palembang, Sumatera Selatan
}

\begin{abstract}
Abstrak: Salah satu keberhasilan siswa dalam pendidikan ditunjukkan oleh prestasi akademiknya. Hal inilah yang belum dimiliki oleh para siswa untuk selalu meningkatkan motivasi berprestasinya. Motivasi berprestasi yang dimiliki seseorang idealnya selalu mengalami kemajuan sehingga akan mempercepat apa yang diinginkan. Tujuan penelitian adalah diketahuinya perbedaan rata-rata motivasi berprestasi siswa kelas IV, V, dan VI SD Negeri Sumber Rahayu OKU Timur tahun 2017. Desain penelitian menggunakan pendekatan kuantitatif. Pengumpulan data menggunakan pedoman observasi dan angket untuk mendapatkan data primer dan sekunder. Teknik analisis data menggunakan independent sample t-test dan ANOVA (One Way ANOVA). Penelitian ini dilaksanakan pada 13 November 2017 s.d 06 Januari 2018 di SD Negeri Sumber Rahayu OKU Timur. Hasil penelitian menemukan jika terdapat perbedaan nilai ratarata motivasi berprestasi siswa kelas IV, V, dan VI SD Negeri Sumber Rahayu OKU Timur tahun 2017. Untuk itu, sebaiknya guru lebih memperhatikan minat dan bakat agar siswa dapat terus meningkatkan motivasinya untuk terus berprestasi, lebih mengetahui cara membuat pembelajaran di kelas menjadi lebih menarik dan menyenangkan sehingga siswa lebih termotivasi untuk mengikuti pembelajaran.
\end{abstract}

Kata-kata kunci: motivasi, motivasi berprestasi, siswa sekolah dasar

\section{DIFFERENCES OF ACHIEVEMENT MOTIVATION STUDENTS OF CLASS IV, V, AND VI ELEMENTARY SCHOOL}

\begin{abstract}
One of the successes of students in education is shown by their academic achievements. This is what students do not have to always improve their achievement motivation. Achievement motivation possessed by someone ideally always progresses so that it will accelerate what is desired. The purpose of the study was to find out the difference in the average achievement motivation of grade IV, V, and VI students of Sekolah Dasar Negeri Sumber Rahayu OKU Timur in 2017. The research design used a quantitative approach. Data collection uses observation and questionnaire guidelines to obtain primary and secondary data. Data analysis techniques using independent sample t-test and ANOVA (One-Way ANOVA). This research was conducted on November 13, 2017 until January 06, 2018 in Sumber Rahayu OKU Timur Elementary School. The results of the study found that if there were differences in the average score of achievement motivation for grade $I V, V$, and VI students of Sekolah Dasar Negeri Sumber Rahayu OKU Timur in 2017. For that reason, teachers should pay more attention to their interests and talents so that students can continue to improve their motivation to continue achieving, more knowing how to make learning in class more interesting and fun so students are more motivated to take part in learning.
\end{abstract}

Keywords: motivation, achievement motivation, elementary school student

\section{PENDAHULUAN}

Guru dalam proses pendidikan di sekolah menurut Syamsuddin (2003) memiliki tugas ganda yaitu sebagai pengajar dan pendidik. Sebagai pengajar, guru bertugas menyampaikan bahan pelajaran kepada anak didik, sedangkan sebagai pendidik, guru bertugas membimbing dan membina anak didik agar menjadi manusia susila yang cakap, aktif, kreatif, dan mandiri.

Setiap guru berharap agar dalam melaksanakan tugas mendidik maupun mengajar dapat dikerjakan dengan lancar tanpa mengalami hambatan baik pelaksanaan pendidikan umumnya maupun 
pelaksanaan pembelajaran di kelas. Guru tentunya berusaha untuk memperbaiki perencanaan dan pelaksanaan pembelajaran serta berusaha memberikan pembinaan dan bimbingan, tetapi guru masih banyak mengalami hambatan dalam melaksanakan pendidikan dan pembelajaran di kelas. Menurut Mulyasa (2008), untuk melaksanakan pendidikan di sekolah dan pembelajaran di kelas dengan baik, guru harus memiliki sejumlah kompetensi, salah satu diantaranya adalah kompetensi pedagogik.

Oleh karena itu, guru harus memiliki kemampuan untuk mempengaruhi siswa yang sedemikian rupa sehingga terjadi proses belajar. Untuk dapat melaksanakan proses pembelajaran yang efektif dan efisien diperlukan suatu kompetensi operasional dalam arti kemampuan yang secara nyata dapat dilakukan dalam melaksanakan proses pembelajaran. Pada pelaksanaan proses pembelajaran, guru harus memahami perkembangan anak dan pedagogik agar tercipta jembatan yang dapat menghubungkan antara kandungan kurikulum dengan pengalaman-pengalaman yang sangat dibutuhkan oleh siswa.

Paradigma pendidikan di Indonesia pada umumnya banyak memerlukan perubahan sehingga guru perlu terus-menerus belajar baik secara kelompok maupun kelembagaan agar didapat metode pembelajaran yang up to date agar diperoleh guru yang mampu mengintegrasikan dan menggunakan skill pengetahuan di dalam kelas. Sebagaimana yang dikatakan oleh Hamzah (2008), guru sebagai pendidik harus mengubah paradigma, dari paradigma apa yang akan diajarkan menjadi cara mengajarkannya.

Layanan pendidikan pada siswa merupakan dasar yang sangat berpengaruh terhadap perkembangan siswa selanjutnya hingga dewasa. Pelaksanaan pembelajaran di sekolah dasar yang selama ini cenderung lebih bersifat akademik perlu dikembangkan ke arah pembelajaran yang sesuai dunianya. Memberikan kesempatan kepada siswa untuk aktif dan kreatif dengan menerapkan konsep belajar sambil berbuat (learning by doing) dan diarahkan pada pembelajaran yang berpusat pada siswa (child centered) dengan menerapkan pembelajaran yang sesuai dengan taraf perkembangan anak sehingga diharapkan motivasi belajar siswa meningkat.

Kenyataan di lapangan yang ditemukan saat observasi awal di SD Negeri Sumber Rahayu OKU Timur bahwa dalam pelaksanaan pembelajaran di kelas masih berpusat pada guru, tidak berpusat pada aktivitas siswa. Siswa juga menganggap sebagian pelajaran tidak perlu atau tidak penting, serta sistem belajar yang diterapkan guru masih monoton dan tidak menggunakan alat bantu (media). Hal inilah yang menyebabkan tingkat keberhasilan siswa dalam prestasi akademik kurang sebagaimana diharapkan oleh sekolah, orang tua, dan siswa itu sendiri. Salah satu keberhasilan siswa dalam pendidikan ditunjukkan dengan prestasi akademiknya padahal tuntutan prestasi akademik pada siswa semakin tinggi sementara daya belajarnya biasa-biasa saja.

Motivasi berprestasi yang dimiliki seseorang idealnya selalu mengalami kemajuan sehingga akan mempercepat apa yang diinginkan. Hal inilah yang belum dimiliki oleh siswa siswi SD Negeri Sumber Rahayu OKU Timur untuk selalu meningkatkan motivasi berprestasinya. Oleh karena itu, untuk mendapatkan hasil belajar yang baik dan maksimal diperlukan persiapan siswa dalam belajar yang baik pula. Persiapan siswa dalam belajar merupakan kebutuhan pokok yang harus dipenuhi oleh siswa dalam mencapai hasil belajar yang baik. Faktor eksternal yang menunjang keberhasilan siswa-siswi SD Negeri Sumber Rahayu OKU Timur salah satunya adalah dengan pemberian les tambahan di luar jam sekolah atau jam sepulang sekolah khusus untuk kelas tinggi, yaitu kelas IV, V, dan kelas VI serta guru pengajarnya adalah guru yang sama untuk semua kelas.

Menurut Djamarah (2002), “Kesiapan untuk belajar jangan hanya diterjemahkan siap dalam arti fisik, tetapi juga diartikan dalam arti psikis dan materil". Kesiapan fisik misalnya kondisi badan yang sehat dan bugar. Kesiapan psikis misalnya ada hasrat untuk belajar, dapat berkonsentrasi, dan ada motivasi instrinsik. Kesiapan materiil misalnya ada bahan yang dipelajari atau dikerjakan berupa buku bacaan atau catatan pelajaran. Kesiapan siswa dalam belajar merupakan kondisi diri siswa yang telah dipersiapkan untuk melakukan suatu kegiatan belajar. Kesiapan diri siswa akan melahirkan perjuangan untuk mencapai yang dicita-citakan Motivasi berprestasi siswa, sebagian besar dimunculkan oleh guru melalui metode pembelajaran yang digunakan. Tujuannya untuk menciptakan pembelajaran menarik dan menyenangkan sehingga dapat memotivasi siswa untuk belajar, karena motivasi belajar merupakan prediktor prestasi belajar yang paling penting.

Menurut Tucker, Zayco, dan Herman (dalam Singh \& Singh, 2013), faktor-faktor lain dapat memengaruhi prestasi belajar hanya dengan memberikan efek terhadap motivasi belajar terlebih dahulu. Faktor yang memengaruhi prestasi belajar anak, meliputi faktor intrinsik dan ekstrinsik. 
Faktor intrinsik berasal dari dalam diri anak, antara lain inteligensi, motivasi, sikap, minat, bakat, dan konsentrasi. Sementara itu, faktor ekstrinsik berasal dari luar diri anak, antara lain keluarga, faktor sekolah, dan faktor masyarakat (Simanjuntak, 2013).

Motivasi berprestasi mempunyai peranan penting dalam hal penumbuhan gairah, merasa senang, dan semangat untuk belajar. Siswa yang memiliki motivasi kuat akan mempunyai banyak energi untuk melakukan kegiatan belajar. Seorang siswa yang memiliki inteligensi cukup tinggi dapat gagal karena kekurangan motivasi. Hasil belajar akan optimal apabila ada motivasi yang tepat. Dimana, motivasi berprestasi adalah berusaha unggul untuk mencapai hasil dan tujuan serta menyelesaikan tugas.

McClelland (dalam Dimyati \& Mudjiono, 2009), mengatakan seseorang mempunyai motivasi untuk belajar karena adanya kebutuhan untuk berprestasi. Heekhausen dalam (Hamzah, 2008) mengemukakan bahwa motivasi berprestasi adalah suatu dorongan yang terdapat dalam diri seseorang sehingga selalu berusaha atau berjuang untuk meningkatkan atau memelihara kemampuannya setinggi mungkin dalam semua aktivitas dengan menggunakan standar keunggulan. Motivasi berprestasi merupakan dorongan ingin tahu yang dapat dikembangkan selama proses pembelajaran, sikap yang membangun dan mendorong untuk meraih hasil belajar, sehingga motivasi berprestasi akan memengaruhi hasil belajar siswa. Adanya dorongan dari dalam diri siswa untuk sukses, bekerja keras, meraih hasil belajar yang lebih baik, dan adanya upaya menghindari kegagalan dalam belajar maka siswa menambah keyakinan dan aktivitas belajar untuk meraih hasil belajar yang lebih baik.

Dengan melihat hasil penelitian yang dilakukan oleh Setyowati (2016), tentang Analisis Motivasi Berprestasi Siswa Kelas V SD Negeri Slerok 4 Kota Tegal bahwa prestasi siswa kelas V SD Negeri Slerok 4 secara keseluruhan sudah memenuhi KKM (Kriteria Ketuntasan Minimal). Motivasi siswa dipengaruhi oleh faktor intrinsik dan ekstrinsik. Faktor intrinsik siswa kelas V SD Negeri Slerok 4, yaitu minat, harga diri, dan prestasi. Faktor motivasi ekstrinsik, yaitu terdapat dari guru, orang tua, dan sekolah.

Selanjutnya, hasil penelitian Taiyeb, Bahri \& Razak (2012) menunjukkan rata-rata nilai motivasi berprestasi siswa untuk belajar biologi sebesar 124.44 (tinggi) berdasarkan skala kategori motivasi berprestasi. Berdasarkan beberapa kajian dan penelitian relevan serta kondisi di lapangan, maka dilakukan penelitian secara ilmiah tentang motivasi berprestasi siswa. Masalah dalam penelitian ini adalah apakah terdapat berbedaan nilai rata-rata motivasi berprestasi siswa di SD Negeri Sumber Rahayu OKU Timur tahun 2017?

Tujuan penelitian ini adalah untuk mengetahui perbedaan rata-rata motivasi berprestasi antara siswa kelas IV, V, dan kelas VI di SD Negeri Sumber Rahayu OKU Timur tahun 2017 yang diteliti berdasarkan aktivitas belajar siswa, baik yang dilakukan selama di sekolah maupun di rumah.

\section{METODE PENELITIAN}

Desain penelitian ini menggunakan pendekatan kuantitatif dan dilaksanakan di SD Negeri Sumber Rahayu OKU Timur. Penelitian ini dilaksanakan pada 13 November 2017 s.d 06 Januari 2018. Metode penelitian kuantitatif dalam penelitian ini menggunakan penelitian komparatif. Populasi dalam penelitian ini adalah seluruh siswa kelas IV, V, dan VI SD Negeri Sumber Rahayu OKU Timur tahun pelajaran 2017-2018 yang berjumlah 65 orang.

Teknik pengambilan sampel menggunakan total sampling yaitu teknik penentuan sampel dengan cara mengambil seluruh anggota populasi sebagai responden atau sampel (Sugiyono, 2013). Adapun jumlah siswa masing-masing kelas dapat dilihat pada tabel 1.

Tabel 1

Jumlah Sampel Penelitian

\begin{tabular}{ccccc}
\hline \multirow{2}{*}{ No } & \multirow{2}{*}{ Kelas } & \multicolumn{2}{c}{ Jenis Kelamin } & Jumlah \\
\cline { 3 - 4 } & & Lk & Pr & Siswa \\
\hline 1 & IV & 8 & 12 & 20 \\
2 & V & 10 & 11 & 21 \\
3 & VI & 12 & 12 & 24 \\
\hline & Jumlah & 30 & 35 & 65 \\
\hline
\end{tabular}

Penelitian ini merupakan penelitian komparasi antara dua sampel yang saling lepas (independen), artinya sampel-sampel tersebut satu sama lain terpisah secara tegas dimana anggota sampel yang satu tidak menjadi anggota sampel lainnya.

Teknik pengumpulan data yang digunakan dalam penelitian ini berupa (1) pengumpulan data sekunder, yaitu dengan melakukan penelaahan teoriteori yang berkaitan dengan topik penelitian yang berasal dari sumber-sumber penelitian kepustakaan dan sangat berguna dalam penyelesaian landasan teori dalam rangka pembahasan permasalahan; dan (2) pengumpulan data primer, yaitu kuesioner.

Instrumen yang digunakan sebanyak 20 
soal. Alternatif jawaban menggunakan model skala likert dengan lima alternatif jawaban yaitu (1) tidak pernah, (2) jarang, (3) kadang-kadang, (4) sering, dan (5) selalu. Responden memilih jawaban yang sesuai dengan pendiriannya atau keadaan yang sebenarnya. Butir kuesioner dinyatakan dalam dua bentuk, yaitu pernyataan yang bersifat positif dan negatif. Artinya, semakin tinggi nilai rata-rata motivasi berprestasi siswa yang diperoleh melalui kuesioner semakin tinggi pula motivasi berprestasi siswa tersebut, begitu pula sebaliknya semakin rendah nilai rata-rata yang didapatkan melalui kuesioner maka semakin rendah pula motivasi berprestasinya.

Setelah diketahui nilai rata-rata (mean) dan standar deviasi secara keseluruhan maka langkah selanjutnya adalah menentukan batasan untuk kategori tinggi, sedang, dan rendah motivasi berprestasi siswa siswi di SD Negeri Sumber Rahayu OKU Timur dengan menggunakan rumus TSR sebagai berikut :

Kategori Tinggi $=M+1 S D$

Kategori Sedang $=\mathrm{M}-1 \mathrm{SD}$ s.d $\mathrm{M}+1 \mathrm{SD}$

Kategori Rendah $=$ M -1 SD

Hasil uji validitas kuesioner motivasi berprestasi siswa telah diujikan pada siswa dan dari sekolah lain diketahui jumlah soal butir pertanyaan yang diuji sebanyak 20 butir pertanyaan dengan $n=20$ didapat nilai $r_{\text {tabel }}=0,444$. Dari 20 item kuesioner didapatkan nilai $\mathrm{r}_{\text {hitung }}$ terendah 0,475 dan tertinggi 0,912 . Maka dapat disimpulkan bahwa uji validitas pada kuesioner motivasi berprestasi siswa untuk tiap butir pertanyaannya dinyatakan valid (20 butir) karena nilai $\mathrm{r}_{{ }_{\text {hitung }}}>\mathrm{r}^{-}{ }_{\text {tabel }}$ lalu hasil uji reliabilitas didapat sebesar 0,943 .

Selanjutnya untuk mengetahui ada atau tidaknya perbedaan rata-rata untuk lebih dari dua kelompok sampel yang tidak berhubungan digunakan rumus (Mean).

$$
\bar{X}=\frac{\sum f i \cdot x i}{\sum f i}
$$

Dimana jika ada perbedaan, rata-rata manakah yang lebih tinggi. Rumusan hipotesis dalam penelitian ini yaitu ada perbedaan motivasi berprestasi antara siswa kelas IV, V, dan kelas VI di SDN Sumber Rahayu OKU Timur tahun 2017.

\section{HASIL DAN PEMBAHASAN}

\section{Hasil}

Hasil uji varian satu jalur (One Way ANOVA) ini didapatkan adanya perbedaan rata-rata motivasi berprestasi siswa kelas IV, kelas V dan kelas VI.
Adapun hasil analisisnya dapat dilihat pada tabel 2.

Tabel 2

Hasil Uji One Way ANOVA

\begin{tabular}{lcccc}
\hline & $\begin{array}{c}\text { Kelas } \\
\text { IV }\end{array}$ & $\begin{array}{c}\text { Kelas } \\
\text { V }\end{array}$ & $\begin{array}{c}\text { Kelas } \\
\text { VI }\end{array}$ & Total \\
\hline $\mathrm{N}$ & 20 & 21 & 24 & 65 \\
Rata-rata & 73,75 & 74,95 & 80,63 & 76,68 \\
SD & 8,416 & 8,726 & 6,296 & 8,280 \\
Minimum & 60 & 50 & 70 & 50 \\
Maksimum & 86 & 89 & 90 & 90 \\
Uji F & 4,985 & & & \\
Signifikansi & 0,010 & & & \\
\hline
\end{tabular}

Berdasarkan tabel 2 hasil analisis di atas, didapat nilai $\mathrm{F}_{\text {hitung }}$ sebesar 4,985; $\mathrm{F}_{\text {tabel }}(3,145)$; nilai $\mathrm{F}_{\text {hitung }}>\mathrm{F}_{\text {tabel }}(4,985>3,145)$, maka $\mathrm{H}_{\mathrm{o}}$ ditolak, dengan nilai signifikansi sebesar 0,010 sehingga dapat disimpulkan bahwa ada perbedaan antara rata-rata motivasi berprestasi siswa kelas IV, kelas V, dan kelas VI SD.

Dari hasil analisis di atas juga didapat nilai ratarata, adapun nilai rata-rata tertinggi ada pada kelas VI SD yaitu sebesar 80,63 dengan standar deviasi $(6,296)$, kelas V SD sebesar 74,95 dengan standar deviasi $(8,726)$, dan kelas IV SD sebesar 73,75 dengan standar deviasi $(8,416)$. Dengan demikian, dari kelas IV, V, dan VISD didapatkan nilai rata-rata sebesar 76,68 dengan standar deviasi $(8,280)$.

Selanjutnya setelah diketahui masing-masing nilai rata-rata dan standar deviasi kemudian ditentukan kategori motivasi berprestasi siswa SD Negeri Sumber Rahayu OKU Timur dengan menggunakan rumus TSR, seperti pada tabel 3.

Tabel 3

Kategori Motivasi Berprestasi Siswa SDN Sumber Rahayu OKU Timur

\begin{tabular}{cccccc}
\hline & \multicolumn{4}{c}{ Skor Nilai } & \\
\cline { 2 - 5 } No & $\begin{array}{c}\text { Kelas } \\
\text { IV }\end{array}$ & $\begin{array}{c}\text { Kelas } \\
\text { V }\end{array}$ & $\begin{array}{c}\text { Kelas } \\
\text { VI }\end{array}$ & $\begin{array}{c}\text { Kelas } \\
\text { IV, V, } \\
\text { VI }\end{array}$ & Kategori \\
\hline 1 & $>82$ & $>84$ & $>87$ & $>85$ & Tinggi \\
2 & $65-82$ & $66-84$ & $74-87$ & $68-85$ & Sedang \\
3 & $<65$ & $<66$ & $<74$ & $<68$ & Rendah \\
\hline
\end{tabular}

Berdasarkan kategori skor tinggi, sedang, dan rendah (TSR) dari tabel 3 di atas selanjutnya pada tabel 4 dikelompokkan dan dimasukkan menggunakan rumus persentase untuk mengetahui distribusi frekuensi motivasi berprestasi siswa SD Negeri 
Sumber Rahayu OKU Timur.

Tabel 4

Distribusi Frekuensi Motivasi Berprestasi Siswa SDN Sumber Rahayu OKU Timur

\begin{tabular}{ccccccccccc}
\hline \multirow{2}{*}{ No } & \multirow{2}{*}{ Kategori } & \multicolumn{2}{c}{$\begin{array}{c}\text { Kelas } \\
\text { IV }\end{array}$} & \multicolumn{2}{c}{$\begin{array}{c}\text { Kelas } \\
\text { V }\end{array}$} & \multicolumn{2}{c}{ Kelas } & \multicolumn{2}{c}{ Kelas } \\
& & & F & $\%$ & F & $\%$ & F & $\%$ & F & $\%$ \\
\hline \multirow{2}{*}{1} & Tinggi & 2 & 10 & 1 & 5 & 6 & 25 & 8 & 12 \\
2 & Sedang & 14 & 70 & 14 & 67 & 18 & 75 & 51 & 79 \\
3 & Rendah & 4 & 20 & 6 & 28 & 0 & 0 & 6 & 9 \\
\hline \multicolumn{2}{c}{ Jumlah } & $\mathrm{n}=20$ & $100 \%$ & $\mathrm{n}=21$ & $100 \%$ & $\mathrm{n}=24$ & $100 \%$ & $\mathrm{n}=65$ & $100 \%$ \\
\hline
\end{tabular}

Berdasarkan tabel 4 distribusi frekuensi di atas diketahui bahwa motivasi berprestasi siswa kelas IV SD dengan kategori tinggi sebanyak 2 orang $(10 \%)$, sedang 14 orang $(70 \%)$, dan rendah 4 orang (20\%). Motivasi berprestasi siswa kelas V SD dengan kategori tinggi sebanyak 1 orang $(5 \%)$, sedang 14 orang $(67 \%)$, dan rendah 6 orang ( $28 \%)$, sedangkan motivasi berprestasi siswa kelas VI SD didapat kategori tinggi sebanyak 6 orang $(25 \%)$ dan kategori sedang 18 orang (75\%). Secara keseluruhan, motivasi berprestasi siswa kelas IV, V, dan VISD didapat kategori tinggi sebanyak 8 orang $(12 \%)$, sedang 51 orang $(79 \%)$, dan rendah 6 orang $(9 \%)$.

Dari hasil di atas untuk melihat lebih jelas ratarata motivasi berprestasi siswa SDN Sumber Rahayu OKU Timur dapat digambarkan melalui gambar 1.

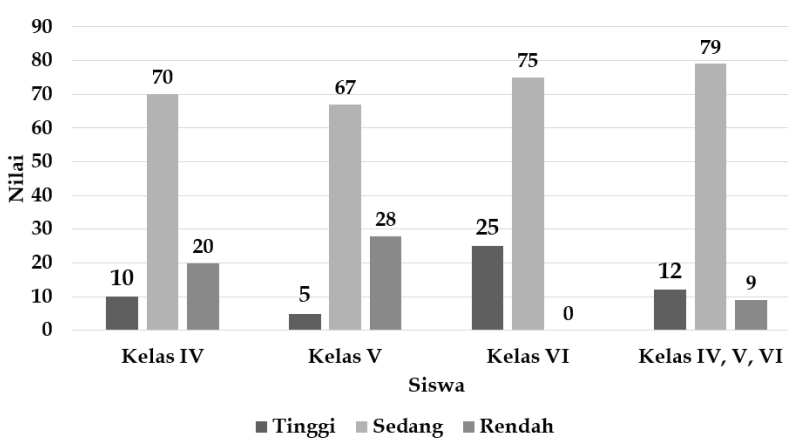

Gambar 1. Kategori motivasi berprestasi siswa SDN Sumber Rahayu OKU Timur

\section{Pembahasan}

Berdasarkan hasil analisis data dan temuantemuan penelitian menunjukkan bahwa ada perbedaan rata-rata antara motivasi berprestasi siswa kelas IV, kelas V, dan kelas VI SD dengan masing-masing rata-rata tertinggi ada pada kelas VISD sebesar 80,63, kelas V SD sebesar 74,95, dan kelas IV SD sebesar 73,75 , sehingga secara keseluruhan didapatkan ratarata 76,68 yang berada pada rentang nilai $(68-85)$ berdasarkan rumus TSR yang digunakan. Hal ini menunjukkan bahwa rata-rata motivasi berprestasi siswa SD Negeri Sumber Rahayu OKU timur secara keseluruhan dengan kategori sedang.

Hasil penelitian menunjukkan bahwa siswa kelas VI SD mempunyai motivasi yang lebih tinggi dibandingkan dengan siswa kelas V SD, dan siswa kelas V SD lebih tinggi motivasi berprestasinya dari siswa kelas IV SD. Siswa kelas VI SD memiliki motivasi berprestasi lebih tinggi karena memiliki kemauan untuk mengulangi pelajaran di luar jam sekolah dan selain itu, rajin mengikuti les tambahan sepulang sekolah. Berdasarkan analisis hasil kuesioner, siswa kelas VI SD selalu melakukan pengulangan terhadap pelajaran yang dirasa sulit sepulang sekolah, membantu teman menyelesaikan tugasnya, menyampaikan hasil kerjanya di kelas, dan mengerjakan PR sepulang sekolah, serta rajin membaca buku pelajaran. Siswa kelas V dan IV SD diperoleh rata-rata motivasi berprestasinya lebih rendah karena dari item-item kuesioner yang ditanyakan, banyak yang tidak selalu dilakukan. Berbagai kegiatan akademi di sekolah dan di sekitarnya, kurang dapat mempengaruhi motivasi belajarnya. Selain dilihat dari indikator yang ada, motivasi berprestasi siswa juga disebabkan karena beberapa faktor seperti peran orang tua, kepercayaan terhadap kemampuan diri sendiri membuat seseorang mampu melakukan suatu hal dalam mencapai tujuannya, adanya penghargaan dari orang lain, dan keinginan untuk sukses.

Dari hasil di atas terlihat bahwa motivasi berprestasi dalam pembelajaran sangat penting untuk diperhatikan. Motivasi berprestasi memberikan sumbangan yang sangat besar pada usaha siswa untuk memperoleh hasil belajar yang optimal. Hal ini sesuai dengan pendapat McClelland bahwa individu yang memiliki motivasi berprestasi tinggi, apabila dihadapkan pada tugas-tugas yang kompleks cenderung melakukannya dengan baik. Apabila berhasil menyelesaikan tugas yang kompleks akan lebih antusias untuk menyelesaikan tugas yang lebih berat dengan lebih baik lagi. Mc Clelland (dalam Hawadi, 2001) menjelaskan bahwa individu yang memiliki motivasi berprestasi tinggi akan memperhatikan kesalahan-kesalahan yang diperbuatnya. Adanya hukuman dan peraturan akan mengurangi tingkat kesalahan yang dibuat oleh individu. Hukuman memiliki tiga fungsi, yakni menghalangi perbuatan yang tidak diinginkan, mendidik anak tentang 
perbuatan yang salah dan benar, dan memberi motivasi untuk menghindari perilaku yang tidak diinginkan. Individu yang memiliki motivasi yang tinggi cenderung memperhatikan kesalahan yang dibuatnya karena adanya hukuman bagi yang melanggar sehingga individu tersebut taat dan mematuhi aturan serta mempunyai kedisiplinan yang tinggi.

Hal ini diperkuat dengan hasil penelitian Sujarwo (2011) bahwa motivasi berprestasi mempengaruhi perolehan hasil belajar. Siswa yang memiliki motivasi berprestasi tinggi memperoleh hasil belajar yang lebih baik dibandingkan dengan siswa yang memiliki motivasi berprestasi rendah. Penelitian dari Moore, dkk (2010) menjelaskan bahwa motivasi berprestasi yang tinggi pada siswa akan membuat siswa lebih terarah dalam bertingkah laku sesuai dengan kemampuan dalam pengembangan pengetahuan.

Berdasarkan hasil penelitian motivasi berprestasi siswa, secara keseluruhan motivasi berprestasi siswa kelas IV SD dengan kategori tinggi sebanyak 2 orang (10\%), sedang 14 orang $(70 \%)$, dan rendah 4 orang (20\%). Motivasi berprestasi siswa kelas V SD dengan kategori tinggi sebanyak 1 orang $(5 \%)$, sedang 14 orang $(67 \%)$, dan rendah 6 orang $(28 \%)$. Motivasi berprestasi siswa kelas VI didapat kategori tinggi sebanyak 6 orang (25\%) dan kategori sedang 18 orang $(75 \%)$. Secara keseluruhan motivasi berprestasi siswa kelas IV, V, dan VI SD didapat kategori tinggi sebanyak 8 orang (12\%), sedang 51 orang $(79 \%)$, dan rendah 6 orang $(9 \%)$.

Perbedaan tersebut tidaklah jauh sehingga dapat ditingkatkan lebih baik lagi dengan bantuan guru kelas, masyarakat, teman-teman, orang tua dan keluarga ataupun orang-orang yang lebih dewasa dari siswa, agar dapat lebih baik dalam membimbing. Dengan demikian, sangatlah penting bagi siswa untuk meningkatkan motivasi berprestasi. Motivasi dapat dibangkitkan dan dikuatkan apabila dalam jiwa anak sudah memiliki rasa membutuhkan terhadap prestasi.

\section{PENUTUP}

\section{Kesimpulan}

Berdasarkan hasil penelitian dapat disimpulkan bahwa terdapat perbedaan nilai rata-rata motivasi berprestasi siswa SD Negeri Sumber Rahayu OKU Timur tahun 2017, dimana siswa kelas IV SD sebesar $(73,75)$, kelas V SD sebesar $(74,95)$, dan kelas VI SD sebesar $(80,63)$. Secara keseluruhan, motivasi berprestasi siswa SD Negeri Sumber Rahayu OKU
Timur dalam kategori sedang.

\section{Saran}

Berdasarkan kesimpulan di atas, maka saran yang dapat disampaikan pertama, pihak sekolah hendaknya memberikan kesempatan pada guru untuk mengikuti pelatihan pembelajaran yang berkaitan dengan pengembangan kompetensi guru terutama kompetensi pedagogik, karena sangat terkait dengan metode dan strategi serta pemanfaatan media dalam pembelajaran.

Kedua, guru perlu lebih memperhatikan minat dan bakat agar siswa dapat terus meningkatkan motivasinya untuk terus berprestasi.

Ketiga, guru perlu lebih mengetahui bagaimana membuat pembelajaran di kelas menjadi lebih menarik dan menyenangkan sehingga termotivasi untuk mengikuti pembelajaran dengan antusias. Guru perlu menyiapkan perencanaan pembelajaran dengan baik, menggunakan strategi pembelajaran yang tepat dan inovatif agar siswa lebih aktif.

\section{DAFTAR PUSTAKA}

Dimyati \& Mudjiono. (2009). Belajar dan pembelajaran. Jakarta: PT. Rineka Cipta.

Djamarah, S. (2002). Prestasi belajar dan kompetensi guru. Jakarta: Usaha Nasional.

Hamzah, B.U. (2008). Teori motivasi dan pengukurannya. Jakarta: Bumi Aksara.

Hawadi, R. A. (2001). Psikologi perkembangan anak: Mengenal sifat, bakat, dan kemampuan anak. Jakarta: PT Grasindo.

Moore, L. L., Grabsch, D. K., \& Rotter, C. (2010). Using achievement motivation theory to explain student participation in a residential leadership learning community. Journal of Leadership Education, 9(2), 22-34. http://www. journalofleadershiped.org/index.php/issues/ vol-9-iss-2/157-using-achievement-motivation-theory-to-explain-student-participation-in-a-residential-leadership-learning-community

Mulyasa. E. (2008). Standar kompetensi dan sertifikasi guru. Bandung: Rosdakarya.

Setyowati, L. (2016). Analisis motivasi berprestasi siswa kelas V SD Negeri Slerok 4 Kota Tegal. Tesis. Semarang: Universitas Negeri Semarang.

Simanjuntak, W. (2013). Faktor-faktor yang mempengaruhi prestasi belajar. Kompasiana. Diakses dari http://www.kompasiana.com/wantisimanjuntak/faktor-faktor-yang-mempengaruhi-prestasi-belajar_552e34eb6ea 83482208b456d pada 
tanggal 2 Mei 2018.

Singh, P., \& Singh, N. (2013). Difficulties in emotion regulation: A barrier to academic motivation and performance. Journal of the Indian Academy of Applied Psychology, 39(2), 289-297. http://jiaap. org/Sample.aspx?Sub=JIAAP\%20July\%202013

Sugiyono. (2013). Metodologi penelitian pendidikan. Bandung: Alfabeta.

Sujarwo. (2011). Pengaruh strategi pembelajaran inkuiri terbimbing dan ekspositori terhadap hasil belajar sosiologi pada siswa SMA yang memiliki tingkat mo- tivasi berprestasi dan kreativitas berbeda. Disertasi tidak diterbitkan. Malang: Program Pascasarjana Universitas Negeri Malang.

Syamsuddin \& Nandang. B. (2003). Profesi keguruan 2. Jakarta: PT. Rineka Cipta.

Taiyeb, A. M., Bahri, A., \& Razak, R. B. (2012). Analisis motivasi berprestasi siswa SMAN 8 Makassar dalam belajar biologi. Jurnal Bionature, 13(2), 77-83. http://ojs.unm.ac.id/bionature/article/ view $/ 1430$ 